\title{
Exploring Affixation in English
}

\author{
Nneka Umera-Okeke
}

\begin{abstract}
:
One of the keys to mastering English spellings is mastering the processes of word formation. The mode of word formation can influence the spelling. The study of the meaningful parts of a word is known as morphology. Linguists have identified many ways in which English form its words which include borrowing from Latin and Greeks, clipping, suppletion, affixation, conversion, acronym, blends, compounding and so on. The scope of this study is to look into affixation as a process of word formation; see the meanings of some of those few letters added at the beginning or end of words, look into the changes words undergo when affixes are added to them. Apart from mastering of spellings, readers of this paper will learn to identify grammatical categories of words by mere looking at the words and identifying the affixes added to them.
\end{abstract}

\section{Introduction:}

Most English words are made up of the base word known as root which contains the heart of the meaning of the word. To expand such words, appendages (affixes) are added at either the beginning or at the end of the word. It is the process of attaching these affixes that is referred to as affixation. The affix added at the beginning of the root is known as prefix while that at the end of a word is suffix. The root is central to the building of new words. For instance, advantage, help, forgive, measure are the core words (roots) 
in disadvantageous, unhelpful, unforgivable and immeasurable respectively. They can be analysed as:

\begin{tabular}{|c|c|c|c|}
\hline $\begin{array}{l}\text { Prefix } \\
\text { Dis- } \\
\text { Un- } \\
\text { Un- } \\
\text { Im- }\end{array}$ & $\begin{array}{l}\text { Root Word } \\
\text { advantage } \\
\text { help } \\
\text { forgive } \\
\text { measure }\end{array}$ & $\begin{array}{l}\text { Suffix } \\
\text { ous } \\
\text { ful } \\
\text { able } \\
\text { able }\end{array}$ & $\begin{array}{l}\text { New Word } \\
\text { disadvantageous } \\
\text { unhelpful } \\
\text { unforgivable } \\
\text { immeasurable }\end{array}$ \\
\hline
\end{tabular}

Despite the fact that prefixes and suffixes are just a combination of two, three or four letters, they have meaning in English. They are therefore morphemes. A morpheme is the smallest meaningful unit of a word. They change the meaning of the root word. In the above examples, dis-, un-, and $i m$ - depict negative. The different approaches to identifying morphemes and the relationships between morphemes and words are reflections of the different trends in linguistics during the twentieth century, but most linguists are in agreement on the type of phenomena morphology is concerned with.

Prefixes and suffixes added to words change the meanings of such words. This study will start with the examination of the meanings of some English prefixes and suffixes.

\section{Meanings of Some Commonly Used Prefixes:}

\begin{tabular}{|l|l|l|}
\hline Prefix & Meaning & Word Examples \\
\hline Bi- & Two; twice; double & Biannual, bilingual \\
Co- & Together with & Co-author, coexist, coeducation \\
de- & away from, down undoing & deport \\
ex- & out & extend, ex-president \\
im- & in or into & immobile, impossible \\
ab- & away from & absent \\
\hline
\end{tabular}




\begin{tabular}{|l|l|l|}
\hline ad- & to, toward & adverb \\
ambi- & both & ambivalent \\
ante- & before; in front of & antenatal \\
anti- & against, opposite; opposed to & antisocial \\
auto- & self; of or by yourself & autobiography, automatic \\
contra- & opposite; against & contradict, contra-flow \\
inter- & among; between & interface, interaction, \\
& international \\
intra- & inside; within & intravenous, intra-departmental \\
hyper & more than normal & hypertension, hypercritical \\
pre- & before & prevent, precondition, preheat \\
semi- & half, partly & semicircle, semi-final \\
sub- & under; below, less than & subtopic, subway, substandard \\
trans- & over, across & trans-Sahara, transport \\
un- & not & unclean \\
super- & above, over, extremely & superhuman, superimpose, \\
& & super structure \\
com & with & combine \\
dis- & not; the opposite of & disadvantage, disappoint, \\
il- & not & dishonest \\
in- & in, on & illogical \\
in- & not & input, inhuman \\
ir- & wrong & irrefutable \\
mis- & not & misprint \\
multi- & more than one; many & multinational, multi-coloured \\
non- & against & nonsense, non-Christian \\
ob- & for, forward & obtuse \\
out- & greater, better, further, longer & outnumber, outgrow, outlive \\
pro- & back, again & proceed \\
post & after & postgraduate, postwar \\
re- & under & repeat, regain \\
sub- & across & subcommittee \\
trans- & across & transcribe \\
self- & of, to or by yourself & self-control, self-taught \\
\hline
\end{tabular}

Note that un-, il-, in-, ir-, non-, mis-, dis- de-mean "not" or "opposite of" in English. The choice of one is governed by phonological conditions: 
Im- is placed before bilabial sounds $/ \mathrm{p}, \mathrm{b}, \mathrm{m} / \mathrm{as}$ in:

$\begin{array}{llll}\text { balance } & \text { imbalance } & \text { possible } & \text { impossible } \\ \text { patient } & \text { impatient } & \text { pure } & \text { impure } \\ \text { mortal } & \text { immortal } & \text { movable } & \text { immovable } \\ \text { modest } & \text { immodest } & \text { potent } & \text { impotent } \\ \text { practical } & \text { impractical } & \text { mature } & \text { immature } \\ \text { perfect } & \text { imperfect } & & \end{array}$

In- is used before alveolar and velar sounds $/ \mathrm{d}, \mathrm{k}, \mathrm{s} /$ and the labio-dental fricative /v/

$\begin{array}{llll}\text { visible } & \text { invisible } & \text { definite } & \text { indefinite } \\ \text { sincere } & \text { insincere } & \text { competent } & \text { incompetent } \\ \text { direct } & \text { indirect } & \text { convenience } & \text { inconvenience } \\ \text { decision } & \text { indecision } & \text { credible } & \text { incredible } \\ \text { dependent } & \text { independent } & \text { curable } & \text { incurable } \\ \text { defensible } & \text { indefensible } & \text { describable } & \text { indescribable } \\ \text { consistent } & \text { inconsistent } & \text { conspicuous } & \text { inconspicuous } \\ \text { coherent } & \text { incoherent } & \text { credulous } & \text { incredulous }\end{array}$

Ir- is used before $r$

$\begin{array}{llll}\text { regular } & \text { irregular } & \text { relevant } & \text { irrelevant } \\ \text { resistible } & \text { irresistible } & \text { responsible } & \text { irresponsible } \\ \text { resolute } & \text { irresolute } & \text { reparable } & \text { irreparable }\end{array}$

II- is used before I

$\begin{array}{llll}\text { logical } & \text { illogical } & \text { legitimate } & \text { illegitimate } \\ \text { legal } & \text { illegal } & \text { literate } & \text { illiterate }\end{array}$

$\begin{array}{llll}\text { Un- } & & \text { de- } & \\ \text { necessary } & \text { unnecessary } & \begin{array}{l}\text { compose } \\ \text { fair }\end{array} & \text { decompose } \\ \text { fortunate } & \text { unfortunate } & \text { formation } & \text { decrease } \\ \text { feformation }\end{array}$




$\begin{array}{llll}\text { just } & \text { unjust } & \text { hydration } & \begin{array}{l}\text { dehydration } \\ \text { interesting }\end{array} \\ \text { uninteresting } & \text { merit } & \text { demerit } \\ \text { happy } & \text { unhappy } & & \\ \text { tidy } & \text { untidy } & & \end{array}$

Dis-

band

disband

courage

honour

illusion

please discourage

dishonour

disillusion

displease non-

commissioned non-commissioned

returnable

static

stick

ferrous non-returnable

non-static

non-stick

non-ferrous

\section{Meanings of Some Commonly Used Suffixes}

\begin{tabular}{|c|c|c|}
\hline Suffixes & Meaning & Words \\
\hline -able & $\begin{array}{l}\text { Capable of being; that can or } \\
\text { must be }\end{array}$ & taxable, changeable, comfortable \\
\hline -age & State, act, or process of, result of & postage, bondage, mileage \\
\hline$-\mathrm{al}$ & Belonging to, process or state of & magical, verbal, betrayal \\
\hline -ance & Act of, state of & dominance, ignorance \\
\hline -ary & Place for; connected with & budgetary, planetary \\
\hline -cy & State of being & democracy, conspiracy \\
\hline -er & $\begin{array}{l}\text { One who is; a person or thing } \\
\text { that }\end{array}$ & teacher, singer, lover \\
\hline -ful & Having the qualities of; full of & sorrowful, forgetful, handful \\
\hline -ist & One whose profession is & dentist, chemist, specialist \\
\hline -less & Lacking, without & sleeveless, selfless, tireless \\
\hline -ly & In the manner of & happily, stupidly \\
\hline -ment & the action or result of & development, bombardment \\
\hline -ness & State of; the quality of & blindness, goodness, dryness \\
\hline -ous & the nature of or having quality of & poisonous, glorious \\
\hline -tion & Act of & education, cooperation \\
\hline -dom & the condition or state of & freedom, kingdom, martyrdom \\
\hline
\end{tabular}

Suffixes are important in determining the meanings of words in English. They are either inflections added at the end of a word or they change the grammatical class of words they are attached to.

\section{Inflectional Suffix/Morpheme:}


Inflection is a major category of morphology. When suffixes are added to words to realize morphemes such as present, past, present participle, plural, they are said to be inflectional. They do not change the nature of the verb to which they are added. For instance:

$$
\begin{array}{llll}
\text { Play } & \text { plays } & \text { playing } & \text { played } \\
\text { Locate } & \text { locates } & \text { locating } & \text { located } \\
\text { Sing } & \text { sings } & \text { singing } & \text { sang }
\end{array}
$$

The suffixes -s, -ing, -ed did not change the word class of the verbs. Bloomfield (1933) referred to inflection as the outer layer of the morphology of word forms. This is because inflections are added when all derivational and compositional processes are already complete. This means that one can add inflection on a root and a stem. Let us take for example the word "disinfectants", the plural inflection - $s$ is added to the stem "disinfectant". The root of the word is "infect". The prefix dis- shows negation or opposite of while the newly derived word is "disinfectant". Inflections such as tense, number, person, etc. will be added to ready-made stems. By stem we mean the forms to which inflections may be added, but which may already have derivational affixes. Other examples are:

\begin{tabular}{l|l|l} 
Root & $\begin{array}{l}\text { Derived Word } \\
\text { /stem }\end{array}$ & \multicolumn{1}{c}{ Inflections } \\
\hline paint & repaint & repaints, repainted, repainting \\
\hline computer & computerize & computerized, computerizing \\
\hline industry & $\begin{array}{l}\text { industrial, } \\
\text { industrialize }\end{array}$ & $\begin{array}{l}\text { industrialization } \\
\text { industrializations }\end{array}$
\end{tabular}


Inflectional categories such as tense, voice and number play important role in syntax and are called morphosyntactic categories, since they affect both the words around them and the words within which they occur. They are very productive and are semantically more regular than the derivational ones; meaning will remain constant across a wide distributional range.

\section{Derivational Suffixes:}

Derivation is the opposite of inflection. It consists of adding an affix or affixes to the root or stem of the word. When this is done, new words are derived. Within derivation, the distinction is often made between class-maintaining and class-changing processes. Class-changing produces a new word in different word class. (E.g. gentle (adj)) gentleness (noun) $\longrightarrow$ gently (adverb)); while class maintaining produces a new word but does not change the class.

\section{Class-Maintaining Derivational Suffixes:}

Examples of class-maintaining suffixes are -age, -ful, ry, -cy, -hood, -ship, -ate, -ure, -ic, -ster, -dom, -ism, -ee, eer. They are used to convert noun to another noun that mean something different. Examples are:

$\begin{array}{llll}\text { acre } & \text { acreage } & \text { spoon } & \text { spoonful } \\ \text { broker } & \text { brokerage } & \text { hand } & \text { handful } \\ \text { front } & \text { frontage } & \text { cup } & \begin{array}{l}\text { cupful } \\ \text { use }\end{array} \\ \text { usage } & \text { mouth } & \text { mouthful } \\ \text { assembly } & \text { assemblage } & \text { house } & \text { houseful } \\ & & & \\ \text { weapon } & \text { weaponry } & \text { lunatic } & \text { lunacy } \\ \text { burglar } & \text { burglary } & \text { magistrate } & \text { magistracy } \\ \text { citizen } & \text { citizenry } & \text { president } & \text { presidency }\end{array}$




\begin{tabular}{|c|c|c|c|}
\hline $\begin{array}{l}\text { knave } \\
\text { machine } \\
\text { chaplain }\end{array}$ & $\begin{array}{l}\text { knavery } \\
\text { machinery } \\
\text { chaplaincy }\end{array}$ & $\begin{array}{l}\text { tenant } \\
\text { truant }\end{array}$ & $\begin{array}{l}\text { tenancy } \\
\text { truancy }\end{array}$ \\
\hline $\begin{array}{l}\text { boy } \\
\text { child } \\
\text { girl } \\
\text { man } \\
\text { priest } \\
\text { woman }\end{array}$ & $\begin{array}{l}\text { boyhood } \\
\text { childhood } \\
\text { girlhood } \\
\text { manhood } \\
\text { priesthood } \\
\text { womanhood }\end{array}$ & $\begin{array}{l}\text { friend } \\
\text { head } \\
\text { judge } \\
\text { owner } \\
\text { scholar } \\
\text { trustee }\end{array}$ & $\begin{array}{l}\text { friendship } \\
\text { headship } \\
\text { judgeship } \\
\text { ownership } \\
\text { scholarship } \\
\text { trusteeship }\end{array}$ \\
\hline $\begin{array}{l}\text { forfeit } \\
\text { portrait } \\
\text { candidate } \\
\text { nuncio } \\
\text { impostor } \\
\text { nomen } \\
\text { electors }\end{array}$ & $\begin{array}{l}\text { forfeiture } \\
\text { portraiture } \\
\text { candidature } \\
\text { nunciature } \\
\text { imposture } \\
\text { nomenclature } \\
\text { electorate }\end{array}$ & $\begin{array}{l}\text { young } \\
\text { song } \\
\text { trick } \\
\text { prank } \\
\text { rhyme } \\
\text { pun }\end{array}$ & $\begin{array}{l}\text { youngster } \\
\text { songster } \\
\text { trickster } \\
\text { prankster } \\
\text { rhymester } \\
\text { punster }\end{array}$ \\
\hline $\begin{array}{l}\text { triumvirs } \\
\text { emir } \\
\text { opium } \\
\text { grant } \\
\text { legacy } \\
\text { mortgage } \\
\text { devotion } \\
\text { chariot } \\
\text { musket } \\
\text { pamphlet }\end{array}$ & $\begin{array}{l}\text { triumvirate } \\
\text { emirate } \\
\text { opiate } \\
\text { grantee } \\
\text { legatee } \\
\text { mortgagee } \\
\text { devotee } \\
\text { charioteer } \\
\text { musketeer } \\
\text { pamphleteer }\end{array}$ & $\begin{array}{l}\text { duke } \\
\text { earl } \\
\text { king } \\
\text { official } \\
\text { cannibal } \\
\text { journal } \\
\text { pauper } \\
\text { critic }\end{array}$ & $\begin{array}{l}\text { dukedom } \\
\text { earldom } \\
\text { kingdom } \\
\text { officialdom } \\
\text { cannibalism } \\
\text { journalism } \\
\text { pauperism } \\
\text { criticism }\end{array}$ \\
\hline
\end{tabular}




\section{Class-Changing Derivational Suffixes:}

Under the suffixes that can change word from one grammatical class to another, we have basically four groups. The presence of the suffixes signal the grammatical class of the words in which they appear. They are:

- Noun Suffixes

- Verb suffixes

- Adjective Suffixes

- Adverb Suffixes

\section{Noun Suffixes:}

Suffix
-dom
-hood
-ness
-ice
-ation
-ion
-sion
-tion
-ment
-ship
-ance
-ence
-ancy
-ism
-ery
-eer
-ist
-or
-er

Meaning state of being state of being state of being act of being act of being act of being act of state of being act of state of being

act of act of state of being act of quality of one who one who believes in one who

one who

Example
freedom
manhood
dimness
cowardice
flirtation
intercession
scansion
corruption
argument
friendship
continuance
precedence
currency
baptism
bravery
auctioneer
fascist
debtor
worker


Verb Suffixes:

Suffix

-ate

-en

-fy

-ize, ise
Meaning

to make

to make

to make

to make
Example

perpetuate

soften

dignify

sterilize

\section{Adjective Suffixes:}

\section{Suffix}

-ful

-ish

-ate

-ic, ical

-ive

-ous

-ulent

-less

-able, ible

-ed

-ly

-like
Meaning

ful of

resembling

to make

resembling

having

full of

full of

without

capable of

having

resembling

resembling
Example

hateful

foolish

affectionate

angelic

prospective

zealous

fraudulent

fatherless

peaceable

spirited

womanly

childlike

Adverb Suffixes:

Suffix

-ly

-ward
Meaning

to make more

in the direction of

\section{Example}

quickly

afterward

\section{Derivation of Words from One Grammatical Class to} Another

Now let us look at how the addition of these suffixes mentioned above can change words from one grammatical category to another: 


\section{Conversion of Verb to Noun}

To derive nouns from verbs, the noun forming suffixes are added to the verb and new words are formed. Some examples are:

i. -ment

amend amendment defile defilement detach detachment incite incitement

embellish embellishment argue argument resent resentment abridge abridgement acknowledge acknowledgement

ii.

$\begin{array}{llll}\text { collect } & \text { collection } & \text { resolve } & \text { resolution } \\ \text { obstruct } & \text { obstruction } & \text { adopt } & \text { adoption } \\ \text { repress } & \text { repression } & \text { adapt } & \text { adaptation } \\ \text { accumulate } & \text { accumulation } & \text { absorb } & \text { absorption } \\ \text { devote } & \text { devotion } & \text { contend } & \text { contention } \\ \text { destroy } & \text { destruction } & \text { pretend } & \text { pretension } \\ \text { recognize } & \text { recognition } & \text { intend } & \text { intention }\end{array}$

Verbs that end in -ate drop e and replace with -ion illustrate illustration meditate meditation demonstrate demonstration pollinate pollination enumerate enumeration stagnate stagnation

\section{iii. -ation}

The suffix -ation is added to some verbs ending in -ise.

The final e is dropped before the addition of -ation.

Examples are:

authorize authorization improvise improvisation

civilize civilization polarize polarization

\section{Others are:}

afforest afforestation derive derivation

crown coronation divine divination 
deprive deprivation fix fixation inhale inhalation

Still on -ation, if the verb ends in ke, the ke is replaced by c before the suffix

convoke convocation evoke evocation

invoke invocation provoke provocation

revoke revocation

Verbs that end in -ain or -aim will drop the i to take -ation

declaim declamation exclaim exclamation

explain explanation proclaim proclamation

abstain abstention

entertain entertainment

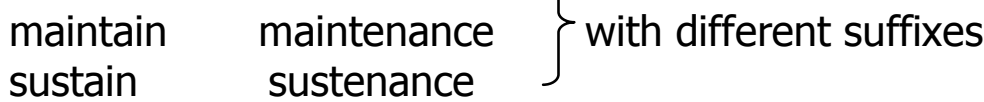

iv -ication

Some verbs ending in -ify drop the $y$ and replace it with -ication beatify beatification gasify gasification sanctify sanctification solidify solidification

\section{Exceptions:}

liquefy

liquefaction (not *liquidification)

putrefy (not *putrify) putrefaction

crucify crucifixion

v. -ition

-ition is attached to verbs ending in -ish. The sh is

dropped and replaced by -ition

abolish abolition admonish admonition

demolish demolition

Other -ish ending words take different suffixes. Examples are:

banish banishment embellish embellishment

furnish furniture/furnishing

-ition can also be attached to verbs ending in -it 
exhibit exhibition fruit fruition

inhibit inhibition prohibit prohibition

Some -it ending words take -ssion (to be discussed later)

vi -ution

Verbs ending in -olve have the ve replaced by -ution absolve absolution devolve devolution evolve evolution resolve resolution revolve revolution

vii. -sion

-sion is applied to some words ending in -ise with the e dropped

excise excision revise revision

supervise supervision

Some words ending in -de drop this ending to take -sion to form noun. Examples are:

$\begin{array}{llll}\text { collide } & \text { collision } & \text { conclude } & \text { conclusion } \\ \text { decide } & \text { decision } & \text { divide } & \text { division } \\ \text { evade } & \text { evasion } & \text { extrude } & \text { extrusion } \\ \text { invade } & \text { invasion } & \text { persuade } & \text { persuasion } \\ \text { provide } & \text { provision } & & \end{array}$

-sion is also added to verbs ending in it. The $t$ is dropped and replaced by -sion to form noun.

$\begin{array}{llll}\text { avert } & \text { aversion } & \text { convert } & \text { conversion } \\ \text { divert } & \text { diversion } & \text { invert } & \text { inversion } \\ \text { revert } & \text { reversion } & & \end{array}$

viii. Double s suffix -ssion

This occurs with verbs ending in -ee or -ede

accede accession concede concession

proceed procession intercede intercession

secede secession supersede supersession 
-ssion is also attracted by some verbs ending in -it emit emission omit omission transmit transmission remit remission/remittance

\section{ix -ant, -ent}

-ant

celebrate celebrant adhere adherent

coagulate coagulant antecede antecedent

confide confidant correspond correspondent

depend dependant deter deterrent

lubricate lubricant precede precedent

migrate migrant preside president

occupy occupant receive recipient

serve servant study student

\section{x. -ance -ence}

These two suffixes are confusing at times. Spellers sometimes find difficulty in remembering which to use of the two.

Verbs with final e drop the e to add -ance. Other verbs without final e also take -ance.

\begin{tabular}{ll}
\multicolumn{2}{c}{-ance nouns } \\
Verbs with final e \\
tolerate $\quad$ tolerance \\
ignore $\quad$ ignorance \\
dominate & dominance \\
grieve & grievance \\
reassure & reassurance \\
remonstrate & remonstrance
\end{tabular}

\begin{tabular}{cl}
\multicolumn{2}{c}{-ance nouns } \\
Verbs without final e \\
react & reactance \\
attend & attendance \\
abbey & abeyance \\
clear & clearance \\
maintain & maintenance \\
perform & performance
\end{tabular}




\begin{tabular}{ll}
\multicolumn{2}{c}{-ence nouns } \\
Verbs with final e \\
adhere & adherence \\
coincide & coincidence \\
condole & condolence \\
confide & confidence \\
precede & precedence \\
subserve & subservience
\end{tabular}

\begin{tabular}{ll}
\multicolumn{2}{c}{-ence nouns } \\
Verbs without final e \\
abhor & abhorrence \\
absent & absence \\
offend & offence \\
infer & inference \\
prominent & prominence \\
obey & obedience
\end{tabular}

The suffixes -ance and -ence can also be used to convert adjectives to nouns.

xi. -ism, -ysis

These suffixes are usually applied to adjectives and nouns. Sometimes, they are applied to some verbs in their conversion to nouns:

criticise criticism

dogmatise dogmatism

plagiarise plagiarism

The suffix -ysis is usually found in scientific vocabulary:

analyse analysis

electrolyse electrolysis

xii. -al

Examples of -al nouns formed from verbs are:

acquit

arouse

avow

betray

rebut

rehearse

withdraw

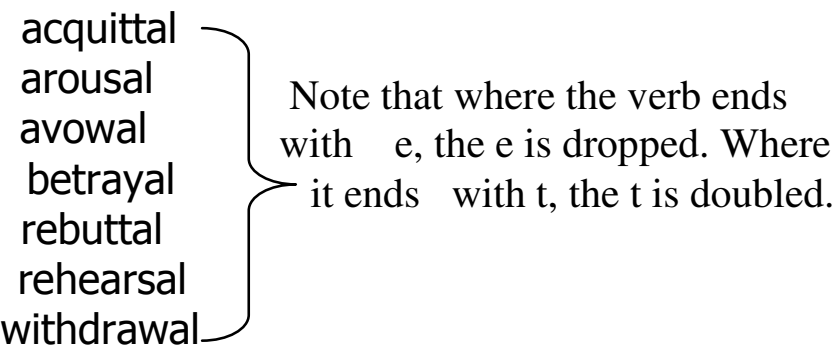




\section{xiii. -age}

-age is generally attached to nouns but in some cases, it is attached to verbs to form nouns:

cleave

use

waste

post

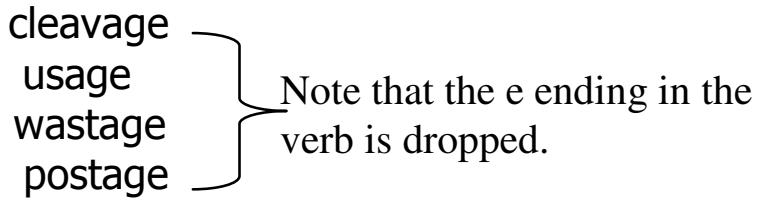

xiv. -ry, -ery

A few verbs are converted to nouns by the suffix ry. The two suffixes are usually attached to nouns. Examples of their attachment to verbs to form nouns are:

bake

mimic

brew

water

$\begin{array}{lll}\text { bakery } & \text { husband } & \text { husbandry } \\ \text { mimicry } & \text { revel } & \text { revelry } \\ \text { brewery } & \text { hatch } & \text { hatchery } \\ \text { watery } & \text { launder } & \text { laundry }\end{array}$

XV. -ure

The suffix - ure converts a few verbs to nouns. Verbs that end in consonants will just take -ure, but those that end in e drop the e before -ure:

$\begin{array}{llll}\text { fail } & \text { failure } & \text { erase } & \text { erasure } \\ \text { forfeit } & \text { forfeiture } & \text { legislate } & \text { legislature } \\ \text { proceed } & \text { procedure } & \text { pose } & \text { posture } \\ \text { invest } & \text { investiture } & \text { seize } & \text { seizure }\end{array}$

-ure is also applied to few adjectives but usually to nouns.

This shall be discussed later.

xvi. -acy

Some verbs are converted to nouns by the use of -acy: conspire conspiracy advocate advocacy 
The suffix is also attached to nouns and adjectives. (to be discussed later)

\section{xvii. Action Suffixes:}

These are suffixes which describe the actions or occupations of people or the uses of things. They include -er, -or, -ant and -ist (or -yst). We also have -ar which is a rare usage. Some examples are:

-er

betray

teach

write

carry

send

inform

magnify

cool

spell

defend -or

\section{act}

vend

convey

sail

decorate

mediate actor

vendor

conveyor

sailor

decorator

mediator

\begin{tabular}{lllll}
\multicolumn{1}{c}{-ant } & & -ist, & -yst & \multicolumn{2}{c}{-ar } \\
Depend & dependant & apologise & apologist beg & beggar \\
Aspire & aspirant & catalyse & catalyst lie & liar \\
Celebrate & celebrant & dramatise & dramatist & \\
Inform & informant & dogmatise & dogmatist & \\
Enter & entrant & anaesthetise & anesthetist & \\
Inhabit & inhabitant & pacify & pacifist & \\
Pollute & pollutant & plagiarise & plagiarist
\end{tabular}

\section{xviii. -ing, -ee, -and}

The last batch of verb to noun suffixes are -ing, -ee, -and. -ing 
The present participle of a verb is sometimes used as a noun ending in -ing.

His singing and dancing was well appreciated.

As a leader, he has a tremendous following.

The launching of the project was successful.

I do not understand his comings and goings.

-ee

Employ

Vend

employee
vendee

Pay

payee

Address addressee

\section{-and}

This is of limited application. An undergraduate about to receive his degree is a graduand. Somebody about to be ordained a priest is an ordinand.

\section{Conversion of Verbs to Adjectives:}

The following suffixes are added to verbs to form adjectives: -able, -ible, -ous, -ive, -ory, -al, -ant, -ent, -some, -f

\section{i. -able}

Some verbs ending in consonants take able without any alteration but if the basic verb end in -ate, this end is dropped and replaced with able:

$\begin{array}{llll}\text { accept } & \text { acceptable } & \text { abominate } & \text { abominable } \\ \text { book } & \text { bookable } & \text { appreciate } & \text { appreciable } \\ \text { comfort } & \text { comfortable calculate } & \text { calculable } \\ \text { favour } & \text { favourable demonstrate } & \text { demonstrable } \\ \text { honour } & \text { honourable educate } & \text { educable }\end{array}$

If the basic verb ends in ce the e is retained but if it ends in $y$ after a consonant, the $y$ is replaced by $i$. Examples are: enforce enforceable descry descriable pronounce pronounceable

pity trace traceable rely pitiable reliable 
The rule however is not robber-stamped as apply is applicable not *'appliable'.

If the basic verb ends in e after a consonant or after $\mathrm{s}$, the $e$ is usually dropped:

$\begin{array}{llll}\text { admire } & \text { admirable } & \text { debate } & \text { debatable } \\ \text { prove } & \text { provable } & \text { use } & \text { usable } \\ \text { move } & \text { movable/moveable } & \end{array}$

The adjective for despise is however despicable.

Finally, if the basic verb ends in y after a vowel, the $y$ is retained:

$\begin{array}{ll}\text { essay } & \text { essay-able } \\ \text { convey } & \text { conveyable } \\ \text { pay } & \text { payable } \\ \text { play } & \text { playable }\end{array}$

\section{ii. -ible}

The number of verbs taking -ible as suffix is limited.

It is often more attracted to nouns. When added to verbs that end in e, the e is dropped, but when the verb ends in t or $d$, the last letter is dropped replaced with -sible or -ssible.

Examples are:

collapse collapsible comprehend comprehensible

force forcible defend defensible

reverse reversible reprehend reprehensible

admit

omit

permit admissible omissible permissible

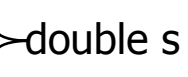

Some exceptions include:

controvert

resist

controvertible resistible

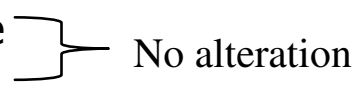

iii. -ous 
The suffix -ous can be added to a few verbs to form adjective:

$\begin{array}{llll}\text { Pretend } & \text { pretentious } & \text { Ponder } & \text { ponderous } \\ \text { Disaster } & \text { disastrous } & \text { Pity } & \text { piteous } \\ \text { Cumber } & \text { cumbrous/cumbersome } & \end{array}$

iv. -ory

This suffix can be added to only few verbs to form adjectives:
Declaim declamatory 7 note that the $\mathrm{i}$ in ai in these words
Explain explanatory $\zeta$ is dropped
Retaliate retaliatory
Inhibit inhibitory

v. -ive

The suffix -ive can be attached to many verbs to derive adjective. Words that end in e drop the e before the suffix but those that end in consonants will simply take the suffix:

$\begin{array}{llll}\text { cumulate } & \text { cumulative } & \text { construct } & \text { constructive } \\ \text { cure } & \text { curative } & \text { express } & \text { expressive } \\ \text { decorate } & \text { decorative } & \text { instruct } & \text { instructive } \\ \text { indicate } & \text { indicative } & \text { possess } & \text { possessive } \\ \text { restore } & \text { restorative } & \text { prevent } & \text { preventive }\end{array}$
speculate speculative

In some words $d$ is replaced by $s$ and some others take the suffix -ative:

$\begin{array}{llll}\text { conclude } & \text { conclusive } & \text { represent } & \text { representative } \\ \text { decide } & \text { decisive } & \text { affirm } & \text { affirmative } \\ \text { divide } & \text { divisive } & \text { confirm } & \text { confirmative } \\ \text { exclude } & \text { exclusive } & \text { preserve } & \text { preservative } \\ \text { include } & \text { inclusive } & \text { conserve } & \text { conservative }\end{array}$


Other examples are:

\begin{tabular}{|c|c|c|}
\hline $\begin{array}{l}\text { apprehend } \\
\text { comprehend } \\
\text { defend } \\
\text { offend }\end{array}$ & $\begin{array}{l}\text { apprehensive } \\
\text { comprehensive } \\
\text { defensive } \\
\text { offensive }\end{array}$ & $\begin{array}{l}\mathrm{d} \text { is dropped and -sive } \\
\text { added }\end{array}$ \\
\hline $\begin{array}{l}\text { permit } \\
\text { submit } \\
\text { admit }\end{array}$ & $\begin{array}{l}\text { permissive } \\
\text { submissive } \\
\text { admissive }\end{array}$ & $\begin{array}{l}\text { s dropped and -ssive is } \\
\text { dded }\end{array}$ \\
\hline
\end{tabular}

vi. -al

The adjectives formed with -al derived from verbs are:

criticize critical

equivocate equivocal

pontificate pontifical

This suffix is commonly used in the conversion of nouns to adjectives.

vii. -ant, -ent

As in the formation of nouns from verbs, these suffixes can also be used to form adjectives:

$\begin{array}{llll}\text { defy } & \text { defiant } & \text { decay } & \text { decadent } \\ \text { please } & \text { pleasant } & \text { deliquesce } & \text { deliquescent } \\ \text { repent } & \text { repentant } & \text { effervesce } & \text { effervescent }\end{array}$

\section{viii -some, -ful}

Some adjectives ending in some derived from verbs are:

$\begin{array}{llll}\text { cumber } & \text { cumbersome } & \text { fear } & \text { fearsome } \\ \text { grue } & \text { gruesome } & \text { quarrel } & \text { quarrelsome } \\ \text { tire } & \text { tiresome } & & \end{array}$

The suffix -ful is attached to few verbs. It is more attached to many nouns to form adjectives. Examples of places where it is added to verbs are:

mourn mournful

revenge vengeful 


\section{Conversion of Adjectives to Nouns:}

Adjectives are converted to nouns by use of the following suffixes: -ness, -ity, -ion, -acy, -ery, -ry, -ment, ism, -ance, -ancy, -ence, -ency, -escence.

\section{i. -ness}

beastly

happy

saintly

busy

sprightly

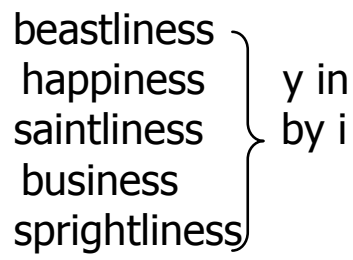

\section{ii. -ity}

The suffix -ity is added to some words without any alteration. In some cases, the e that ends the base adjective is dropped:

$\begin{array}{llll}\text { fluid } & \text { fluidity } & \text { agile } & \text { agility } \\ \text { humid } & \text { humidity } & \text { diverse } & \text { diversity } \\ \text { infirm } & \text { infirmity } & \text { ductile } & \text { ductility } \\ \text { morbid } & \text { morbidity } & \text { infinite } & \text { infinity } \\ \text { senior } & \text { seniority } & \text { profane } & \text { profanity } \\ \text { normal } & \text { normality } & \text { pure } & \text { purity } \\ \text { plural } & \text { plurality } & \text { nude } & \text { nudity }\end{array}$

iii. -ion

A few adjectives attract the suffix -ion to form nouns: abject abjection contrite contrition discreet discretion resolve resolution dissolve dissolution

iv. -acy, -ery, -ry, -ment

Only few adjectives attract these suffixes to form nouns. They are:

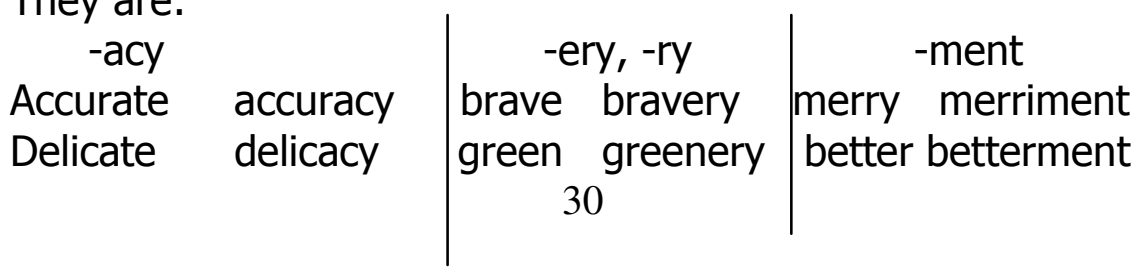


Obstinate obstinacy

Profligate profligacy

Supreme supremacy

v. -ism

-ism is mostly used for converting nouns to nouns. It, however, can be added to few adjectives to form nouns:

$\begin{array}{llll}\text { Altruistic } & \text { altruism } & \text { American } & \text { Americanism } \\ \text { Archaic } & \text { archaism } & \text { Colloquial } & \text { colloquialism } \\ \text { Monetary } & \text { monetarism } & \text { Mystic } & \text { mysticism } \\ \text { True } & \text { truism } & \text { Witty } & \text { witticism }\end{array}$

vi. -ance, -ancy, -ence, -ency

These four suffixes are common in converting adjectives to nouns. Some examples are:

\begin{tabular}{llll}
\multicolumn{2}{l}{-ant to -ance } & \multicolumn{2}{c}{-ant to -ancy } \\
abundant & abundance & constant & constancy \\
attendant & attendance & expectant & expectancy \\
dominant & dominance & hesitant & hesitancy \\
elegant & elegance & infant & infancy \\
relevant & relevance & vacant & vacancy \\
-ent to ence & \multicolumn{2}{c}{-ent to } & -ency \\
corpulent & corpulence & absorbent & absorbency \\
prominent & prominence & clement & clemency \\
reticent & reticence & consistent & consistency \\
subsistent & subsistence & fluent & fluency
\end{tabular}

vii. -escence

Adjectives ending in escent form nouns ending in escence. Examples are:

Acquiescent acquiescence Coalescent coalescence Convalescent convalescence Fluorescent fluorescence Effervescent effervescence Deliquescent deliquescence 


\section{viii. -iety}

$\begin{array}{llll}\text { anxious } & \text { anxiety } & \text { dubious } & \text { dubiety } \\ \text { pious } & \text { piety } & \text { proper } & \text { propriety } \\ \text { sober } & \text { sobriety } & \text { various } & \text { variety }\end{array}$

\section{Conversion of Nouns to Adjectives:}

The suffixes for converting nouns to adjectives are: $-y$, -ly, -ish, -ous, -ic, -ics, -ical, -ary, -ar, -ful, -less, -al, -ial, -eal, -ate, -ine, -ian, -ean, -ese, -en, -esque, -able, -ible, -ose, -iac.

\section{i. $-\mathbf{y},-$ ly}

haze

lace lacy

beast

beastly

sauce

friend

friendly

saucy

king

kingly

day daily

mother

motherly

ii. -ish

hour hourly

week

weekly

book

fever

iii. -ous

bookish boy boyish

Apart from using -ous to convert verbs to adjectives and adjectives to nouns, it can also be used to convert nouns to adjectives. Examples are:

$\begin{array}{llll}\text { peril } & \text { perilous } & \text { clamour } & \text { clamorous } \\ \text { poison } & \text { poisonous } & \text { dolour } & \text { dolorous } \\ \text { portent } & \text { portentous } & \text { glamour } & \text { glamorous } \\ \text { anomaly } & \text { anomalous } & \text { humour } & \text { humorous } \\ \text { calamity } & \text { calamitous } & \text { number } & \text { numerous } \\ \text { glory } & \text { glorious } & \text { mischief } & \text { mischievous } \\ \text { pity } & \text { piteous } & \text { disaster } & \text { disastrous } \\ \text { Avarice } & \text { avaricious } & \text { adventure } & \text { adventurous } \\ \text { Caprice } & \text { capricious } & \text { fibre } & \text { fibrous } \\ \text { Malice } & \text { malicious } & \text { pore } & \text { porous } \\ \text { Space } & \text { spacious } & \text { luster } & \text { lustrous }\end{array}$




$\begin{array}{llll}\text { iv. }- \text { ic, } \text {-ics, } \text {-ical } & & \\ \text { aesthete } & \text { aesthetic } & \text { drama } & \text { dramatic } \\ \text { athlete } & \text { athletic } & \text { hero } & \text { heroic } \\ \text { tone } & \text { tonic } & \text { giant } & \text { gigantic } \\ \text { economy } & \text { economic } & \text { geography } & \text { geographic } \\ \text { harmony } & \text { harmonic } & \text { melody } & \text { melodic }\end{array}$

When applied to special studies the suffix -ic is pluralized.

Adjectives formed from such nouns drop the $s$ and extend the suffix to -ical. Examples are:

$\begin{array}{lcll}\text { Acoustic } & \text { acoustical } & \text { Economics } & \text { economical } \\ \text { Ethics } & \text { ethical } & \text { Mathematics } & \text { mathematical } \\ \text { Physics } & \text { physical } & \text { Politics } & \text { political }\end{array}$

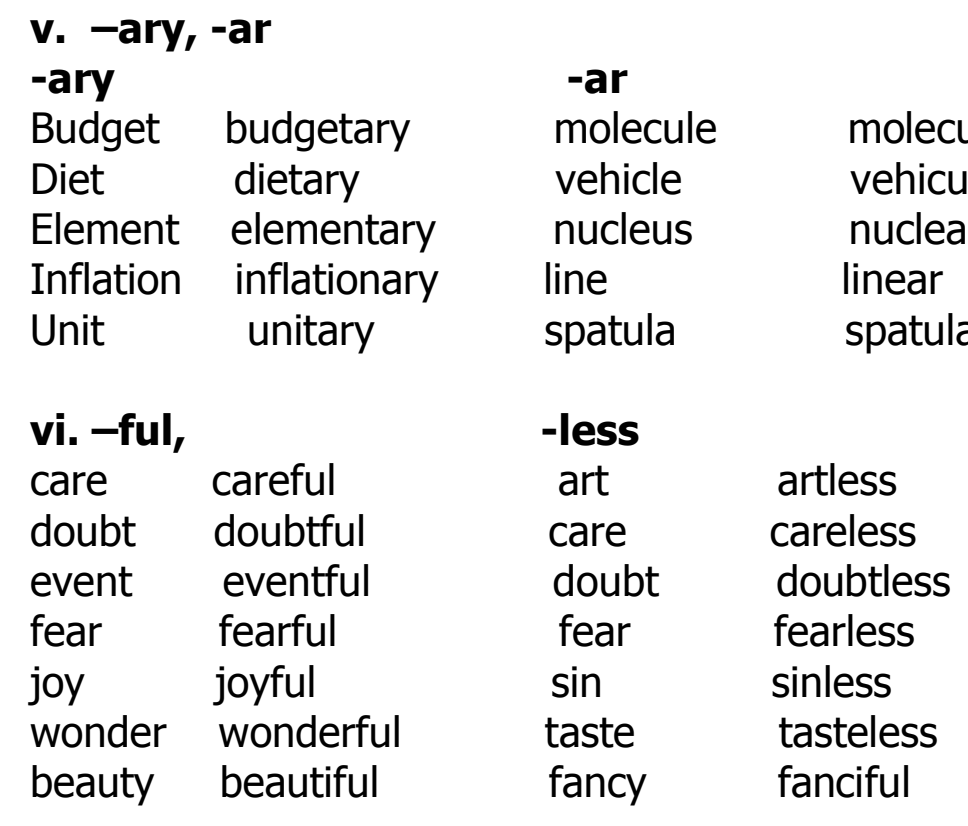

Other adjectives formed from nouns are: 


$\begin{array}{llll}\text { Incident } & \text { incidental } & \text { adamant } & \text { adamantine } \\ \text { Verb } & \text { verbal } & \text { alkali } & \text { alkaline } \\ \text { Exception } & \text { exceptional } & \text { crystal } & \text { crystalline } \\ \text { Race } & \text { racial } & \text { Christ } & \text { Christian } \\ \text { Substance } & \text { substantial } & \text { earth } & \text { earthen } \\ \text { Remedy } & \text { remedial } & \text { gold } & \text { golden } \\ \text { Fashion } & \text { fashionable } & \text { honour } & \text { honourable }\end{array}$

\section{Conversion of Nouns to Verbs:}

Some nouns can be converted to verbs by the addition of the following suffixes:

-en (or $-n)$, -ify (or fy), -ise (or ize) and -ate

i. -en (or $-n)$

length lengthen

strength strengthen

height heighten

ii. -ise,

carbon carbonize

idol idolize

liquid liquidize

vapour vapourise

motion motivate -ify (or -fy)

beauty beautify

example examplify

stupor stupefy

-ate

carbon carbonate

hyphen hyphenate

liquid liquidate

action activate

\section{Conversion of Adjectives to Verbs:}

A common suffix for this purpose is -en or the prefix en- as in:

$\begin{array}{llll}\text { black } & \text { blacken } & \text { dear } & \text { endear } \\ \text { bright } & \text { brighten } & \text { large } & \text { enlarge } \\ \text { deep } & \text { deepen } & \text { rich } & \text { enrich } \\ \text { loose } & \text { loosen } & \text { noble } & \text { ennoble } \\ \text { tight } & \text { tighten } & \text { white } & \text { whiten }\end{array}$




\section{Conclusion:}

This study has shown the important role of affixation in word formation process in the English language. The list is inexhaustible. Some prefixes and suffixes are only inflections added to words to pluralise, change tense or mark comparative and superlative forms of adjectives. Some others, as we have seen, are class- changing suffixes. The mastery of these affixes will lead to a good mastery of English spellings.

\section{References}

Bright, W.(ed.)(1992). International Encyclopedia of Linguistics. New York: Oxford University Press.

Crystal D. (1997) The Cambridge Encyclopedia of Language. Second Edition. New York: Cambridge University Press. Frank, Marcella (1980) Writing as Thinking: A Guided process Approach. New Jersey: Prentice-Hall, Inc.

Hornby A. S. Oxford Advanced Learners' Dictionary of Current English. 7th Edition. Oxford University Press.

Johnson B.E (1992) Doing It Right: Improving College Learning Skills. Toronto- Canada: Heath and Company. Metacalfe J. E. and C. Astle (MCMXCV) Correct English.

England: Clarion 